\title{
THE LEND-LEASE PROGRAM AND POST-WAR PATENT CLAIMS
}

\section{Richard Spencer $\dagger$ and LaUrence I. Wood $\ddagger$}

\section{Introduction}

The conviction that the United Nations will eventually emerge successfully from the present world conflict is gradually giving rise to an awareness of the importance of preparing now for the solution of post-war problems.

One of the more difficult phases of the return to normalcy will be the settling of accounts both at home and abroad. Lack of an adequate pre-formulated policy for the balancing of international debits and credits has in the past resulted in our being widely criticized. Thus we entered the peace negotiations that followed the last war with woefully inadequate planning or means of co-ordination. Lacking the experience of some of our allies, we came away from Versailles with little more than I. O. 'U.'s and, in instances, a feeling of ill will on the part of those beside whom we had fought.

Post-war claims commissions endeavored to eliminate the chaos in the deluge of controversies over the wartime use of private property rights. We finally washed official hands of the matter, leaving claimants to such relief as lay in their long and uphill remedy against the Government via the Court of Claims.

We are as a nation presently determined not to lose the peace that lies ahead. As one important aspect of that peace, we must endeavor to achieve an equitable and intelligent balancing of the international books. This is no plea for the attitude of the persistent creditor; it is instead a statement of the importance of now recognizing, insofar as is possible, the problems which will arise, and of eliminating in advance by the sure cure of prevention as many as possible of those problems.

The transfer of goods abroad in World War II has been under the authority of the Lend-Lease Act; a full and complete account of the tremendous exchange of food, goods, personnel, information, and

$\dagger$ A. B., I924, George Washington University; LL. B., I927, Harvard University; Lecturer on Law, Northwestern University; author of U. S. Patent Law System; First-Assistant Commissioner of Patents, 1932-1936; member of the National Advisory Council to the Committee on Patents, House of Representatives, 1936-1940; presently Assistant Chief of the Procurement Legal Division (in charge of patent matters), Office of the Under Secretary of the Navy.

$\ddagger$ A. B., 1936, DePauw University; J.D., 1939, Northwestern University Law School; author of Patents and Antitrust Law; Attorney for Procurement Legal Division, Patent Section, Office of the Under Secretary of the Navy; member of the Chicago Bar. 
services is being compiled by the Office of Lend-Lease Administration. The transfer is effected by the various Departments of the Government which purchase from the producers in this country and lend-lease to the transferee governments abroad. Against the immense credit being thereby accrued is to be set up the reverse lend-lease, arising through the feeding of American troops, the supplying of services, information, and bases. Whether any further settlement of national accounts will be effected must remain a matter of international policy on a high plane. ${ }^{1}$

The protection, however, of the rights of individuals whose property is affected by the lend-lease transactions is a matter which will obviously require treatment either now or in the post-war era. Toward the elimination of litigation and delay in this field much can and should be done before the termination of hostilities. One particularly significant phase of the problem is that relating to compensation for the use of patents in our world-wide war production program.

The necessity for protection of the rights of patent owners affected by the transfer of goods or information is expressly recognized in Section 7 of the Lend-Lease Act which provides that: ${ }^{2}$

"The Secretary of War, the Secretary of the Navy, and the head of the department or agency shall in all contracts or agreements for the disposition of any defense article or defense information fully protect the rights of all citizens of the United States who have patent rights in and to any such article or information which is hereby authorized to be disposed of and the payments collected for royalties on such patents shall be paid to the owners and holders of such patents."

Beyond its apparent purpose of protecting patentees, this provision is of little visible help, being as it is utterly devoid of clarity. This is attested to by the Attorney General who states: ${ }^{3}$

"I . . . understand that this contemplates protection of the rights of all classes of inventors who may come within the scope of the section, but, of course, leaves for the future the determina-

I. The determination of that policy will involve consideration of the published letter of transmittal of the Eleventh Report to Congress on Lend-Lease Operations, filed August 25, I943, as compared with the President's later comment thereon.

In the letter as published the President said: "The Congress in passing and extending the Lend-Lease Act made it plain that the United States wants no new war debts to jeopardize the coming peace. Victory and a secure peace are the only coin in which we can be repaid." These sentences were later written off in a presidential press conference as erroneous. It was there explained that the recipient nations will repay as far as they possibly can, but not necessarily in dollars. However, it is clear that it is the intention that there shall be no staggering war debts.

2. 55 STAr. 33, \$ 7 (I94I), 22 U. S. C. A. \$4I6 (Supp. 1943). See also the corresponding provision (Section 6 ) in the Act of June 15 , 1940, relating to military. and naval assistance to the American Republics. 54 STAT. 397, 22 U. S. C. A. §526 (I940).

3. Letter of Attorney General, Dec. 20, 1941, to the Secretary of War. 
tion of the existence of any such rights and of the persons entitled to protection. . . . It also appears improbable that all the uncertainties inherent in this section will be finally solved without litigation or further legislation." 4

A more satisfactory solution and preventative of post-war problems may be found in understandings such as the Patent Interchange Agreement between Great Britain and the United States. ${ }^{5}$ The primary purpose of this agreement is to promote and facilitate the wartime exchange of information, designs, and patent rights under the authority of the Lend-Lease Act. Its essence is the provision that each government will upon the request of the other obtain insofar as is practicable any patent rights or information owned by its own citizens or nationals. And under a proposed reciprocal indemnity each government is to be insured against the claims of citizens or nationals of the other country, insofar as those claims arise out of rights transferred under the agreement. $^{5 a}$ This latter provision. in particular will guarantee that each government, to the extent exchanges under the agreement are concerned, will be called on to pay only the claims of its own citizens. Furthermore, each government agrees to obtain now, insofar as is possible,

4. Two questions immediately arise with reference to Section $7:$ (I) Does it create any new substantive rights in citizens who have patents, or merely require protection of existing rights? For example, does it contemplate giving protection against foreign use of a patented invention, although the patentee has only a United States patent? If it creates no new rights, why is the provision included? The second query is somewhat related: (2) Does Section 7 extend protection to owners of United States patents only, or to owners of foreign patents as well? These, and other uncertainties must at some time be clarified, either by court decision or by additional legisiation. Apparently, however, the provision has been of some value in preventing knowledge of an invention from becoming public property in foreign countries. In his report to the Congress on June II, I94I, Sen. Doc. No. 66, 77th Cong., Ist Sess., President Roosevelt stated at p. 13: "Before any defense articles were transferred, the Ambassador or the duly accredited officer of the foreign government receiving defense articles was required to make the necessary agreement and give the requisite assurances that his government would comply with Sections 4 and 7 of the Act of March II, I94I. These agreements and assurances provide in substance that no defense article or defense information received by the foreign nation under the Lend-Lease Act will be turned over to anyone not an agent, officer, or employee of such government without first obtaining the consent of the President."

And in his report of March II, 1942, H. R. Doc. No. 66r, 77th Cong., 2d Sess., at p. 34, he said: "The countries receiving aid have agreed not to permit the transfer of any lend-lease material or information, or its use by anyone not an officer, employee, or agent of their governments, without our consent. They have undertaken to protect the interests of citizens of the United States who have patent rights in and to any articles or information transferred."

For a discussion of these provisions, see Fenning, Lend-Lease Patent Operations (I942) 24 J. PAT. OFF. Soc. 7I3. That the protection of this section will be limited to assurance against the invalidating effect of publication and public use, see Elirs, Patent Assignments and Licenses ( $2 \mathrm{~d}$ ed. r943) 540.

5. Interchange of Patent Rights, Information, Inventions, Designs, or Processes; Executive Agreement Series 268, August 24, 1942.

5a The British Government has already granted such an indemnity to this country; a draft of the American counterpart is at this writing still in the process of negotiation between the two Governments. 
licenses for the use of the patents of its own nationals. This is the most important part of the wartime activities under the agreement, for by the obtaining of adequate licenses the governments can eliminate altogether post-war patent claims of any sort, between these two governments and their nationals. Exactly what constitutes an adequate license is, as will be seen, a question demanding some close attention.

The two serious limitations on the effectiveness of the Patent Interchange Agreement as a solution of post-war claims are that it is directed primarily at obtaining the immediate exchange of patent rights regardless of the post-war consequences, and it includes only two of the allied nations in its scope.

It is evident that there must be created in the post-war days a commission for the settling of the claims and the solving of the problems arising from patent use during the war. This was done after World War I, when the Secretary of War, under the Dent Act, ${ }^{6}$ the Bolling Commission, ${ }^{\top}$ the Interdepartmental Radio Patents Board, ${ }^{8}$

6. 40 Stat. I272 (I9I9), as amended, 42 Stat. 322, 50 U. S. C. A. $\$ 80$ (Ig2I). Pursuant to the authority of Section 3 of this statute, the Secretary of War appointed a Commission to receive and consider claims for reimbursement for the use of foreign inventions by the United States during the war. The Commission held hearings in I93I in both England and France. It was a prerequisite to the filing of any claim that the claimant stipulate that he would accept any award made by the Commission as a full and final settlement of his claim, and that he would be forever barred from submitting it to any other tribunal. Some sixteen claims were heard by the Commission amounting to a total of approximately $\$ 250,000,000.00$. The Commission negotiated agreements with the claimants and recommended to the Secretary of War payment of some $\$ 240,000.00$.

7. This Joint United States-British Commission sat in London in I922-23 to consider claims filed by British nationals. It was created pursuant to the "Bolling Agreement" entered into by representatives of the two countries. The Agreement lacked the dignity of a treaty but was a war measure made pursuant to authority of the Dent Act. The history of this matter begins with the appointment of Colonel Bolling by the Secretary of War to negotiate an aircraft agreement with England during the war. The two countries agreed to the exchange of information concerning aircraft developments. Colonel Bolling was afterward killed in action, but the subsequently created Commission bore his name.

This agreement is in a sense a limited forerunner of the present United StatesUnited Kingdom Patent Interchange Agreement. Note 5 supra. Both Army and Navy officers served on the Commission; it approved claims in the sum of approximately $\$ 50,000.00$ and the claims were paid.

8. The activities of this Board are described in the Report of the Interdepartmental Radio Board, May 3I, I92I. It was created by the Secretary of War, the Attorney General, and the Secretary of the Navy to investigate and negotiate a settlement of claims against the United States by owners of radio patents. The Board was organized on August 16 , I9I8, and "began the preparation of a complete detailed statement of the radio apparatus which has been bought, constructed and used by the War and Navy Department. . . ." Id. at 9. Twenty-four claims were presented to the Board by radio patent owners, demanding an estimated twenty million dollars. The Board recommended the payment of some two million dollars. Congress, however, refused to honor the findings of the Board, and the claimants were left to their remedy in the Court of Claims. The Report makes it clear that: "This Board has not, in its consideration of the various claims that have been brought before it, assumed to exercise a judicial function. It has had in view its position as a governmental agency, acting on the part of the Government, for ascertaining such reasonable compensation as may be allowed to the various claimants on a basis of settlement without suit." Id. at I2. 
and the War Claims Arbiter ${ }^{9}$ were all active in attempting to iron out the innumerable tedious and troublesome problems.

It is equally evident, however, that such a commission would be immensely more effective if created now so that with careful foresight it might act to eliminate in advance problems otherwise destined to complicate our return to the normalcy of peace. Those designated to act after November II, I9I8, were well nigh hopelessly handicapped by the suddenness with which the problems were deluged upon them. The inevitable result was that disappointed claimants turned finally to the remedy of action in the Court of Claims-a remedy impaired by the interminable nature of the proceedings.

To the end that we may intelligently act in the matter of creating such a commission, ${ }^{10}$ and delegating to it an adequate sphere of activity, it is essential that we examine carefully the nature of the problems

9. The Arbiter was appointed by the President pursuant to the Settlement of War Claims Act of I928, 45 STAT. c. I67, \&3. That statute expressly permitted the filing of claims by German nationals for compensation for any patent which had been licensed, assigned, or sold by the Alien Property Custodian to the United States or for the use by or for the United States of any patent seized and held by the Custodian. The statute fixed the maximum total award which could be made by the Arbiter, and directed the Secretary of the Treasury to pay any amounts not exceeding that total which were certified by the Arbiter. The Arbiter's awards were approximately one-tenth of the maximum allowed.

Io. The problem of the authority for creation of such a commission is a significant one. Following World War I, the United States Liquidation Commission-War Department, was established by the Secretary of War, General Orders No. 24, on Feb. II, I9rg. According to the Final Report of the Commission (I920) at p. I2: "It was believed that, under the legislation existing at the time, the Secretary of War could, by direction of the President and as an incident to the war, create such a commission and clothe it with suitable power to dispose of these claims and of these surplus stocks."

The statutes so relied on were the Act of May 10, 1912, and the Act of July 9, I9I8, both authorizing sales of war supplies to associated nations and to individuals and corporations. The question was not free from doubt: "In order, however, that all possible doubt on the legality of the Commission's power might be removed, Congress passed an Act which became law on March 2, 1919, conferring power on the Secretary of War, 'through such agency as he might designate or establish, to make equitable and fair adjustments' of claims arising out of wartime agreements or negotiations."

This statute was the Dent Act, 40 STAT. 1272, cited note 6 supra. Immediately after the passage of the Act, General Orders No. 40, designated the Commission as the agency through which the powers should be exercised. There is today no statute corresponding to the Dent Act. The grant contained in the First War Powers Act, 55 STAT. 838, 50 U. S. C. A. $\$ 601$ (I94I), is expressly limited to such action as the President deems "would facilitate the prosecution of the war. . . ." However, the Lend-Lease Act, 55 STAT. 3I, 22 U. S. C. A. \$4I6 (r94I), confers on the President broad powers not limited to the war itself. He is authorized by Section 3 to make and procure any defense article, and to sell, transfer, or exchange it to the government of any country whose defense he deems vital to the United States. Moreover: "The terms and conditions upon which any such foreign government receives any aid authorized . . shall be those which the President deems satisfactory. . ." These powers are limited only by the expiration date fixed in the statute, which may be expedited by a resolution of the two Houses. They are apparently broad enough to permit the disposal of any post-war stocks, and possibly the settlement of any claims of foreign governments arising out of the lend-lease program. However, further authority may well be necessary for the handling of purely domestic claims, and an overall statute of the nature of the Dent Act would remove any question of power. In this connection it is perhaps significant that of the four major groups working to settle patent claims after World War I, the recommendations of the three constituted pursuant to statutory authority were recognized; the findings of the Board set up by the departmental heads were not accepted by the Congress. 
destined to arise. It is not the purpose of these paragraphs to attempt in any way to offer the solution to the complex problems ahead. Rather it is the attempt to point out some of the danger zones, and to urge that action be taken now to avoid those areas of conflict while there is yet time.

\section{Patents and the Lend-Lease Program}

The interesting and challenging aspect of the impact of the patent laws upon our lend-lease program is that this field is thus far totally unexplored. Yet it needs careful charting lest the termination of the war result in a blast of unforeseen litigious technicalities and difficulties.

The basis of the patent problems peculiarly associated with lendlease activities is that many inventors acquire patents in more than one country for the same invention. Each of these patents constitutes a distinct and separate property right, although they describe and relate to the identical discovery. This is because the patents granted by each country are co-extensive in point of the territory they cover only with the jurisdiction of the country creating the patent. ${ }^{11}$ The owner of a United States patent is protected against infringement only in the United States and its territories. Consequently, infringement of that patent cannot be predicated on acts consummated in a foreign country. ${ }^{12}$ When one of the elements of a patented combination is made and sold for export to be assembled abroad, there is no infringement of the United States patent, either direct or contributory. ${ }^{13}$ It could not be the latter for there is no "infringement" to which the manufacture and sale could contribute. "Contributory infringement can only arise in this country when somewhere and somehow in this country there is a completed infringement to which a contribution can be made." 14

For the same reason that a United States patent gives no protection against acts committed outside of our territories, those tortious acts do constitute infringement of the patent controlling in the country where they are committed, and this is true even though the making and

II. See Walker, Patents (Deller ed. I937) II82; Rev. Stat. $\$ 4884$ (I875), 35 U. S. C. A. $\$ 40$ (I940).

I2. Dowagiac Mfg. Co. v. Minnesota Moline Plow Co., 235 U. S. 64 I, 35 Sup. Ct. 221, 59 L. Ed. 398 (1915); In re Amtorg Trading Corp., 75 F. (2d) 826 (C. C. A. 3d, I935), cert. den., 296 UU. S. 576,56 Sup. Ct. I02, 80 L. Ed. 407 (I935).

I3. Bullock Elec. \& Mfg. Co. v. Westinghouse Elec. \& Mfg. Co., I2g Fed. I05 (C. C. A. 6 th, Ig04).

I4. Computang Scale Co. v. Toledo Computing Scale Co., 279 Fed. 648, 678 (C. C. A. 7th, I92r) ; and see Bullock Elec. \& Mfg. Co. v. Westinghouse Elec. \& Mfg. Co., I29 Fed. 105 (C. C. A. 6th, 1904), cited note 13 supra; Sutton v. Gulf Smokeless Coal Co., 77 F. (2d) 439, 44I (C. C. A. 4th, 1935). But see R. C. A. v. Andrea, 90 F. (2d) 612 (C. C. A. 2d, I937) (where all the elements of a patented combination are made here and shipped together for assembly abroad it constitutes contributory infringement). 
selling in this country are with the permission of the owner of the United States patent. ${ }^{15}$

From this brief summary it is at once apparent that there may arise any number of complex situations out of lend-lease transfers abroad.

\section{British Patent Law}

The patent law of the country where the "infringing" acts occur is, of course, controlling as to whether there is actual infringement or not. ${ }^{16}$ Where the United States makes and ships a patented article to Great Britain, infringement of the British patent must be predicated on use of the article in the British Isles. ${ }^{1 \tau}$ Suit therefor would be in the British courts against either the British Government or the individuals making the infringing use. ${ }^{18}$

The United States, as we have noted, is proposing to give an indemnity to the British against claims of United States nationals who own patents, where the rights are transferred under the Patent Interchange Agreement. To determine what steps are necessary to guard against liability under that indemnity we must, therefore, inquire into the British law regarding patent infringement.

The general English rule is in accord with the United States doctrine cited above, namely, that an article made pursuant to a patent in one country will nevertheless infringe a corresponding British patent when used in England. Thus, where the owners of patents in Belgium and England granted a license to one person to manufacture under the invention in Belgium, but not elsewhere, it was held that the grant of

15. Curtiss Aeroplane and Motor. Corp. v. United Aircraft Eng. Corp., 266 Fed. 7I (C. C. A. 2d, I920) ; T. C. Weygandt Co. v. Van Emden, 40 F. (2d) 938 (S. D. N. Y. I930).

I6. See Grissinger v. United States, $77 \mathrm{Ct}$. Cl. I06, I4I et seq. (1933), cert. den., 290 U. S. 676, 54 Sup. Ct. Ior, 78 L. Ed. 583 (1933) (Court of Claims applied French patent law to determine validity and infringement of French patent. See note I 8 infra).

17. Where, however, the British Government transfers the article with its troops to a third country it may there infringe another foreign patent owned by the U. S. inventor. The patentee's recourse in this case would be a suit against representatives of the British Government in the third country, in which case the patent laws of that country would govern.

I8. However, in the interesting case of Grissinger v. United States, $77 \mathrm{Ct}$ Cl. 106 (1933), cert. den., 290 U. S. 676, 54 Sup. Ct. Ior, 78 L. Ed. 583. (1933), Congress by a special act permitted a patentee to sue the United States in the Court of Claims for an alleged infringement of a foreign patent committed in the foreign country. Prior to World War I, the plaintiff had obtained patents covering long distance telephone repeaters in the United States, France, England, Italy, and Belgium. During the war, the A. E. F. installed and used I9 repeater stations in France, in conjunction with its own telephone system. In August, 1919, the United States sold the entire telephone system to France. Since all alleged acts of infringement occurred abroad, no suit could have been brought against the United States in the United States without the specific legislation. Since the alleged tort consisted of violation of a French patent, the court considered the question of validity and infringement of that patent in the light of the French law. The patent was held invalid. 
the license did not imply permission to sell the manufactured article in England, in violation of the English patent. ${ }^{19}$

"Conversely, if the patentee had assigned his patent rights in England, he could not manufacture in France and sell in England, and the sale by him of an article in France would carry with it no implied right to import into or sell in England." 20

However, where the patentee himself makes and sells the patented article without limitation in one country, he sells it free of restriction, and the purchaser may import and sell it in England, if the rights in both countries are vested in one and the same person. ${ }^{21}$ Similarly, if there are no patent rights in the place of manufacture, the manufacturer may not make and sell the article there and then restrain the purchaser from selling or using the article in England, although it is covered by an English patent. ${ }^{22}$

Where, therefore, a United States manufacturer owns both the United States and British patents covering a particular article, his manufacture and sale of the article would free it from any liability to the British patent. This is in accord with the United States rule applicable in the converse situation. ${ }^{23}$ It is to some extent analogous to the rule evolved in the territorial restriction cases, which hold that one who buys patented articles from the manufacturer or one authorized to sell them becomes possessed of an absolute property in the articles, unrestricted in time or place. ${ }^{24}$ To be sure, the international situation is

I9. Societe Anonyme des Manufactures de Glaces v. Tilghman's Patent Sand Blast Co, L. R. 25 Ch. D. 177 (1833).

20. Terreil, Patents (8th ed. I934) I84.

2I. Betts v.. Willmott, L. R. 6 Ch. App. 239, 245 (I89r).

22. A purchaser with notice of a special agreement restricting foreign use is bound by it. Incandescent Iight Co. v. Cantelo, I2 P. O. R. 264 (I855) ; Incandescent Light Co. v. Brogden, I6 P. O. R. 183 (I856). Such an agreement would not be binding on purchasers without notice. Betts v. Willmott, L. R. 6 Ch. App. 239 (I87I), cited note 2I supra. The United States rule is in accord. See EzLIS, op. cit. supra note 4 , at 703-4. Even though the United States and foreign rights are vested in the same individual the rights of a purchaser from that individual to re-sell or use in another country may be bound by suitable notice attached to the goods. Dickerson v. Tinling, 84 Fed. 192 (C. C. A. 8th, I897). See also Daimler Mfg. Co. v. Conklin, I7o Fed. 70 (C. C. A. 2d, 1909) ; Dickerson v. Matheson, 57 Fed. 524 (C. C. A. 2d, I893).

23. Curtiss Aeroplane and Motor Corp. v. United Aircraft Eng. Corp., 266 Fed. $7 I_{1} 78$ (C. C. A. 2 d, 1920); Holiday v. Mattheson, 24 Fed. 185 (C. C. S. D. N. Y. 1885). And see Dickerson v. Matheson, 57 Fed. 524, 527 (C. C. A. 2d, I893).

24. Adams v. Burke, I7 Wall. 453, 456, 2I L. Ed. 700,703 (1873) ; Hobbie v. Jennison, I49 U. S. 355, 362, I3 Sup. Ct. 879, 880, 37 L. Ed. 766, 768 (I893); and Keeler v. Standard Folding Bed Co., 157 U. S. 659, 664, I5 Sup. Ct. 738, 740, 39 L. Ed. 848,850 (I895). On the question of notice, the language of the Court in the Keeler case is significant. Id. at $666, \mathrm{I}_{5}$ Sup. Ct. at $74 \mathrm{I}, 39 \mathrm{I}$. Ed. at $85 \mathrm{I}$. "Whether a patentee may protect himself . . . by special contracts brought home to the purchasers is not a question before us. - ." Also roughly analogous to the principal rule is our doctrine limiting a patentee to one recovery of damages and profits, so that when he has recovered from one who infringed by making and selling articles he is barred from further suits for infringement against the users of the specific articles covered by the decree. Stebler v. Riverside Heights, 214 Fed. 550 (C. C. A. 9th, I9I4); Sherman, Clay and Co. v. Searchlight Horn Co., 225 Fed. 497 (C. C. A. 9th, I9I5). 
distinguishable on the ground that two distinct property rights are involved rather than one. For this reason there can be no exhaustion of foreign patent rights by reason of a sale in this country. However, the inherent equity of the situation supports the established rule which, in effect, prevents the patentee from selling his patented article twice to the same person-once in the United States, and once in England.

Where, however, the patent owner, instead of himself making and selling pursuant to the patented invention, licenses another under his United States patent, the use in England of patented articles made here under that license would constitute infringement of the British patent. ${ }^{25}$ The patentee has conveyed only such right as he has in the United States patent, and there can be no implied right to use accompanying the articles wherever they go, as in the previous case, for the manufacturer and seller does not have that right to convey. ${ }^{26}$

Probably, too, the same rule would apply to goods made and sold by or for the United States Government, pursuant to patents used under the provisions of the I9ro-1918 Acts. The Government in thus exercising its power of eminent domain ${ }^{27}$ is not a licensee, ${ }^{28}$ but like a licensee it can take only such rights as are contained in the United States grant. Foreign use of the articles, therefore, would infringe foreign patents.

It should be noted here that due to a peculiar English doctrine, English process patents would be infringed by the importation and use

25. P. 378 supra. A licensee whose rights are limited to the manufacture and sale for use in this country may not sell here with knowledge that the goods are to be exported. Dorsey Revolving Harvester Rake Co. v. Bradley Mfg. Co., Fed. Cas. No. 4,015 (C. C. N. D. N. Y. 1874) ; Elliott Co. v. Lagonda Mfg. Co., 205 Fed. I52 (D. C. W. D. $\mathrm{Pa}$. I9I3). It should be noted that mere purchase, transport, or posession does not amount to infringement, unless it involves use of the invention. TERRELL, op. cit. supra note 20 , at 179 . However, it may justify an injunction as constituting a threat to use. Adair v. Young, L. R. 12 Ch. D. I3 (1879) (Pumps were fitted on board a British ship; injunction granted, although no evidence of use.). Use of an invention on foreign ships, aircraft, and land vehicles which go temporarily into England does not, by statute, constitute infringement. Section 48 of the Patents and Designs Acts. As to foreign aircraft, alleged to be or to contain infringing devices, Section $I 3$ of the Air Navigation Act, 1920, prevents their detention or arrest during passage through or over the British Isles, upon the deposit of a security.

26. Caldwell v. Vanvlissengen, 9 Hare $4 \mathrm{I} 5$ (1851). The United States rule is in accord. In Boesch v. Graff, 133 U. S. 697, 702, 10 Sup. Ct. 378, 380, 33 L. Ed. 787, 789 (I890), the Court said: "The exact question presented is whether a dealer residing in the United States can purchase in another country articles patented there, from a person authorized to sell them, and sell them in the United States, without the license or consent of the owners of the United States patent. - . The right which Hecht had to make and sell the burners in Germany was allowed him under the laws of that country, and purchasers from him could not be thereby authorized to sell the articles in the "United States in defiance of the rights of patentees under a United States patent." See also Dickerson v. Matheson, 57 Fed. 524 (C. C. A. 2d, I893) ; Daimler Mfg. Co. v. Conklin, 170 Fed. 7o (C. C. A. 2d, Ig09). Cf. Adriance, Platt and Co. v. McCormick Harvesting Machine Co., 55 Fed. 288 (C. C. N. D. I11. I893).

27. Crozier v. Krupp, 224 U. S. 290, 32 Sup. Ct. 488, 56 I. Ed. 77 I (19Ir).

28. Cramp \& Sons v. International Curtis M. T. Co., 246 U. S. 28,38 Sup. Ct. 27I, 62 L. Ed. 560 (I9I8). 
there of unpatented products made pursuant to the patented process in the United States. The English rule is summarized by Terrell : ${ }^{29}$

"In the case of a patent for a process or for a machine, the sale in this country of goods manufactured by that process or machine is an infringement. . . . Such a sale is also an infringement even though the manufacture took placè abroad."

\section{In Wright $v$. Hitchcock ${ }^{30}$ the court said:}

"If the law were otherwise, then when a man has patented an invention . . . another might, by merely crossing the Channel, and manufacturing abroad, and selling in London for far less than the original price, but also at a trifle less than the price charged by the patentee, articles made by the patented process, wholly deprive the patentee of the benefit of his invention. It is therefore impossible to suppose that an exclusive right to vend is not given, and the defendants have therefore infringed the plaintiff's rights. . .." 31

Consequently, where a licensee, or the United States, either produces and exports patented articles, or produces and exports unpatented articles pursuant to a patented process, use of the articles in England would infringe the patents there. ${ }^{32}$

One query which will be of tremendous post-war significance arises in the case where a patent owner licenses the United States Government

29. Terrell, op. cit. supra note 20, at I73. See also Townsend v. Haworth, I. R. Ch. D. 83I ; Wright v. Hitchcock, L. R. 5 Ex. 37 (1870). And see Elmslie v. Boursier, L. R. 9 Eq. 2I7; Von Heyden v. Neustadt, L. R. I4 Ch. D. 230 (I880).

30. Wright v. Hitchcock, I. R. 5 Ex. 37, 45 (1870).

3I. This doctrine is, however, not without its complexities. In the first place, it is necessary that the article should have been produced as a direct result of the use of the patented process or machine, and if the patent covers only a minor improvement upon a machine, or in a process, already known, the importation of the product will not constitute infringement. See Wilderman v. F. W. Berk and Co., Ltd., 42 R. P. C. 79. (Patent covered improvement in part of electrolytic process for producing caustic potash. No evidence of materiality of improvement in production of the potash. Held: no proof the importation and use of the potash was infringement of the patent.) However, the stage at which a patented process has been used in the manufacture of the article is not material. Saccharin Corp., Ltd. v. Anglo-Continental Chemical Works, I7 R. P. C. 307. The burden of proving that the articles were in fact made by the patented process is normally on the plaintiff, Cartsburn Sugar Rfg. Co. v. Sharp, I $R$. P. C. I8I ; TERRELL, op. cit. supra note 20 , at 175 , except where the invention relates to the production of a new substance. See $\$ 38 \mathrm{~A}(2)$, PATENTS AND DEsigns Acts. But where the articles are made abroad so that the plaintiff cannot easily inspect the machinery on which they were made, it is incumbent upon the defendant to rebut a prima facie case made out by the plaintiff. Saccharin Corp. v. Dawson, Ig R. P. C. 169; Saccharin Corp. v. Jackson, 20 R. P. C. 6rI ; Saccharin Corp. v. Mack and Co., 23 R. P. C. 25 ; Saccharin Corp. v. National Saccharin Co., Itd., 26 R. P. C. 654 . And see British Thomson-Houston Co., Itd. v. Charlesworth, Peebles and Co., 40 R. P. C. 426,456 . And by statute, where the invention relates to a new substance, the burden of proof is on the defendant. Section $38 A(2)$, supra.

32. The United States rule is contra. In re Amtorg Trading Corp., 75 F. (2d) 826 (C. C. P. A. I935). Where the owner of both the United States and British process patents produced and sold unpatented articles here, their use in England would not, presumably, constitute infringement of the English patent. P. 379 sitpra. 
under his United States patent, knowing that the Government proposes to manufacture the articles and lend-lease them to Great Britain. Would it be held that this situation is analogous to that wherein the patentee himself makes and sells and thereby impliedly consents to the use of the articles abroad? He has, to be sure, received a royalty for the manufacture here, and to that extent the two cases are similar. Of course, in the situation where the patentee has already bargained away his foreign rights there could be no such implied license to use the articles abroad-for here again he has no power to give such a right.

This latter aspect also is one which will be of some significance, for the preponderance of our large patent owners have long ago given exclusive rights under their foreign patents to a foreign corporation, in exchange for similar privileges in respect to the United States patents of the foreign company. Where the two companies are totally distinct entities it is evident that only the foreign company is capable of dealing with the rights in the foreign patent. Another query arises, however, with regard to the case where the foreign corporation is a wholly-owned subsidiary of the United States patent owner. Any case of this sort would theoretically turn largely on the equity of the particular situation: the intent of the parties; the time of the transfer; and so on. But it is highly unlikely that any intent to evade this particular rule of law could be established. However, the court might well consider whether as a matter of principle two legal branches of one economic entity were to be permitted to avail themselves of such a rule.

As a practical matter the problem is not one which directly concerns our Government since the claim of infringement would be by a foreign subject against the foreign government for the violation of a foreign patent. Conceivably, of course, the suit might be brought against a United States official stationed abroad, as in the case of military supplies sent to our armed forces, in which case we should be obligated to defend. If the infringement occurred in Great Britain, the British would indemnify us for any recovery made by its subjects. We could avoid even the nuisance of suit in such a case by requesting a license of the British Government under the Patent Interchange Agreement, but such a request in all probability ${ }^{33}$ will not be made unless the likelihood of infringement is foreseen. There will be many cases where charges of infringement spring from nowhere. And where the Patent Interchange Agreement is not applicable we shall have no indemnity, and, if we do not act, no license.

33. Presumably, under the Patent Interchange Agreement we might request of the British Government a license under all the patents it has granted. See note 5 supra. 
This much is apparent, then, from a hasty glance at the law pertinent to our lend-lease program: for every patented article which we send to the British Isles we are incurring a potential liability to the United States owners of British patents under which we have no license; we are submitting ourselves to suit by the owners of every British patent under which we have not asked the British for a license. For every patented article we send to any country in the world other than Great Britain we are incurring a potential liability to the owners of any patent issued by such country under which we have no license.

In most cases our actual liability will turn on the interpretation of the patent laws of each foreign country. Such a situation it is the obvious duty of the Government to avoid by the securing, at this time, of rights to all such foreign patents as threaten to impinge upon our furnishing of lend-lease aid.

\section{Patents of Governmental Employees}

A second set of unsolved problems concerning lend-lease shipments arises from our law with regard to patents of governmental employees.

The courts of the United States have evolved, in a long series of decisions, a rule which prescribes in just what circumstances an employee will have full and exclusive rights to his patent or invention; ${ }^{34}$ those in which he will have all commercial rights while his employer maintains a shopright or license; ${ }^{35}$ and those in which the employer receives the complete right and title in the patent or discovery. ${ }^{\mathbf{3 6}}$ These rules are held to be the same for governmental employees as for those in the services of private industry, ${ }^{37}$ except as modified by the Act of I9I0-I9I8, which expressly excludes the former from rights given to other inventors. ${ }^{38}$

34. United States v. Burns, I2 Wall. 246, 20 L. Ed. 388 (1870) ; Unițed States v. Palmer, 128 U. S. 262,9 Sup. Ct. 104, 32 L. Ed. 442 (1888).

35. McClurg v. Kingsland, I How. 202, iI L. Ed. 102 ( I843) ; Solomons v. United States, I37 U. S. 342, Ir Sup. Ct. 88, 34 L. Ed. 667 (1890); Lane and Bodley Co. v. Locke, I50 U. S. I93, I4 Sup. Ct. 78, 37 L. Ed. 1049 (I893). See United States v. Dubilier Condenser Corp., 289 U. S. I78, I88, 53 Sup. Ct. 554, 557-8, 77 L. Ed. III4, III9 (I933).

36. Standard Parts Co. v. Peck, 264 U. S. 52, 44 Sup. Ct. 239, 68 L. Ed. 560 (I924). See Hapgood v. Hewitt, II9 U. S. 226, 7 Sup. Ct. I93, 30 L. Ed. 369 ( I893); Dalzell v. Dueber Watch Case Mfg. Co., I49 U. S. 3I5, I3 Sup. Ct. 886, 37 L. Ed. 749 (I893); United States v. Dubilier Condenser Corp., 289 U. S. 178, 187, 53 Sup. Ct. 554, 557,77. L. Ed. III4, III8 (1933).

37. United States v. Burns, I2 Wall. 246, 20 L. Ed. 388 (I870) ; United States v. Palmer, I28 U. S. 262, 9 Sup. Ct. 104, 32 L. Ed. 442 (I888); Solomons v. United States, I37 U. S. 342, 346, II Sup. Ct: 88, 89, 34 L. Ed. 667, 669 (I890) ; McAleer v. United States, I50 U. S. 424, 14 Sup. Ct. I60, 37 L. Ed. II30 (1893); Gill v. United States, 160 U. S. 426, 435-7, r6 Sup. Ct. 322, 326-7, 40 L. Ed. 480, 483-4 (1896); United States v. Dubilier Condenser Corp., 289 U. S. I78, I89-92, 53 Sup. Ct. 554, 558-9, 77 L. Ed. III4, III9-2I (I933).

38. The governmental employee cannot, under 35 U. S. C. A. $\$ 68$, sue the Government for use of his patent while he is employed by the Government, nor for the use of "any, device discovered or invented by such employee during the time of his employ- 
Unfortunately, in none of the decisions is there any attention paid to the query as to what the rule is as to foreign patent rights. Nor is there any decision as to whether the rights which the Government obtains-whether complete title, or a shopright-are in the patent granted to the employee, or in his invention. The words are used interchangeably by the courts; ${ }^{39}$ yet obviously the whole character of the foreign patent rights can be affected by the choice between these concepts. If the rights obtained by the Government are solely in the patent-i. e. the United States patent-then the employee would preserve the absolute right to obtain and exploit foreign patents covering the same invention, to the exclusion of the rights of the United States. If, however, the Government receives title ${ }^{40}$ or a shopright in the inven-

ment or service." This prohibition obviously goes much farther than the rule promulgated by the courts, for it would deny recovery for use of a patent resulting from the employee's activities wholly outside his hours and line of duty. That the Congress had no intention of limiting the rights of employees to this extent is evident from the discussion on this particular portion of the statute on the floor of the House. The primary purpose of the proviso, which was added on the floor, was to guard against claims of employees who perfected inventions on Government time. Although the benefits of the Act were denied to Government inventors, it was understood that they might have recourse to special legislation. Such a privilege is at best unwieldy; there is deemed to be no valid reason why the rule should not be the same for such employees as for all others.

39. Cf. United States v. Dubilier Condenser Corp., 289 U. S. 178, I88, I92, 53 Sup. Ct. 554, 558, 559, 77 L. Ed. III4, III9, II2I (I933), the definitive case in this field. One of numerous examples of the interchange of terms is: "Recognition of the nature of the act of invention also defines the limits of the so-called shop-right, which shortly stated, is that where a servant, during his hours of employment, working with his master's materials and appliances, conceives and perfects an invention for which he obtains a patent, he must accord his master a non-exclusive right to practice the invention." (Italics supplied.) "The United States is entitled, in the same way and to the same extent as a private employer, to shop-rights, that is, the free and non-exclusive use of a patent which results from effort of its employee in his working hours and with material belonging to the Government." (Italics supplied.) See also the Report of the Interdepartmental Patents Board, Sen. Doc. No. 83, 68th Cong., Ist Sess. (I923): "Legally, in the absence of a contract providing otherwise, any patent taken out by a Government employee and any invention developed while in the service of the Government is the sole property of the employee to do with as he may see fit. . . "”

40. It has been recently suggested that when the Government receives title to a patent it "is the cancelation of all patent rights, and reduces the patent document to a publication of the invention therein described." ( $P$. 129) Wille, Government Ownership of Patents (1943) I2 FornEAM L. REv. 105, 129. This remarkable conclusion is based on the proposition that since it is "we, the people of the United States" who delegated its powers to the Federal Government-and any powers not so delegated remain with us-and since "Nowhere in the Constitution any powers not so delegated delegation to the federal government . . . o of the right to exclude others from making, using, and selling any invention which has been disclosed" (p. III), therefore, it is we, the people alone who have the right to any patent transferred to the Government. To arrive at this result the author is of course compelled to tread very lightly over Article IV, Section 3 of the Constitution which gives Congress the express power "to dispose of and make all needful rules and regulations respecting . . . property belonging to the United States."

A patent is property, for all that it is intangible, in just as real a sense as is land or money. It is no more subject to confiscation than either of the others. The owner of any of the forms of property has, within the boundaries marked by public policy, the right to exclude others from the use of that property. That the Government is, under the Constitution possessed of the power to exclude us, the people, from real property which it owns is scarcely open to question; nor are we, the people, free to walk into our mints and freely partake of our currency; from these we may be excluded by the Government, because it owns them. When the Government chooses, through its proper 
tion itself, it would logically follow that any patent covering that invention, wherever obtained, would be subject to the rights of the United States. Shipments of lend-lease goods by the United States would be free of infringement claims regardless of where they were used, where the United States had a title to the invention. It could even be urged, where goods are used for lend-lease purposes, that such a use is for governmental purposes, and consequently that the shopright, being in the invention itself, would extend wherever United States goods are sent. For presumably any assignee of the foreign patents would take them subject to that shopright. It might be held, however, that the shopright of the United States is limited to its own territory, as that of the manufacturer is to his own factory. ${ }^{41}$ But such a holding would, in effect, negate the existence of a shopright in the foreign patent, since it could never be infringed in the United States.

Various departments and agencies have attempted to resolve some of these difficulties by means of employment contracts and regulations concerning the employees' rights. In the large part the regulations wisely seek to do no more than set forth the law pertaining to this field as evolved by the courts. ${ }^{42}$ For it is problematical as to whether an order of an administrative official which sought to deprive either the Government or an employee-inventor of patent rights, as established by the courts, would be valid. ${ }^{43}$ The Supreme Court in the Dubilier

agents, to admit those of us who care to enter public parks at a stipulated admission fee, it could scarcely be designated a direct tax; when the Government loans money, it may legally charge interest; no more is a royalty paid to the Government for use of its patents an unconstitutional levy. (Cf. p. II7.)

It is true that a patent is frequently spoken of as being based on the theory of a contract-a quid pro quo; it does not follow that ( $p$. IIg) since "a party cannot contract with himself" the Government cannot hold title to a patent without its disappearing. The patent itself is a property right, and although it be granted via a contract, as were land claims in the last century, it does not. follow that as the contract terminates the patent expires with it, any more than the land of a grub staker would dissolve and disappear if he conveyed his land back to the Government.

If, as the author seems to imply (pp. 1I6-8) the final answer should turn on the wisdom and "public policy" of having the Government own patents, the question would appear to be more of the manner in which patents are held and utilized by the Government than of its power vel non to so hold. This is the province of the legislature. See Spencer, United States Patent Law System (I93i) 39-4I. Cf. U. S. Const. Art. I, $\S 8$, cl. 8 .

- 4I. Cf. The statement of Stone, dissenting in United States v. Dubilier Condenser Corp., 289 U. S. I78, 217, 53 Sup. Ct. 554, 568, 77 L. Ed. III4, II34 (I933) : "For the work to be successful, the government must be free to use the results for the benefit of the public in the most effective way. A patent monopoly in individual employees . ; would destroy this freedom; a shop-right in the govermment would not confer it."; (Italics supplied.)

42. Typical of these are the Navy regulations, General Order No. 3I, May I3, 1935. These regulations provide in effect that foreign rights shall be disposed of in the same manner as United States rights: the Government will in some cases have full title; in some, a license; and in some, no rights whatsoever.

43. Such a regulation would be particularly questionable as to employees hired prior to its effective date, since there could be no implied consent to such provisions. 
case strongly suggested a total absence of such power in administrative officials. ${ }^{44}$

The Department of Interior Regulations, ${ }^{45}$ however, depart considerably from the current legal formula as to employees' rights. They also provide that the employee shall retain all foreign rights regardless of the status of his United States patent, unless the Secretary should determine that private ownership of such rights would be contrary to public policy. Regulations affecting foreign patent rights could more easily be supported since there is no Constitutional or statutory authority for such rights. They do, of course, constitute property, of which no citizen may be unreasonably deprived. It is doubtful whether the Secretary in making the determination as to "public policy" could consider the fact that the foreign rights would be used as the basis for claims involving lend-lease shipments; presumably the determination would rest more on considerations of security, anti-social monopoly, and similar factors.

The Department of Agriculture has recently issued regulations directed specifically to the problem of governmental rights in foreign patents. ${ }^{46}$ No foreign application may be filed on an employee's invention "in anywise pertaining to the work of the Department" without official approval. If, in the circumstances, title to the invention is in the United States, the foreign application must contain the stipulation that the invention "may be manufactured and used by or for the Government of the United States of America for governmental purposes without the payment of any royalty thereon . . .." If the United States is entitled to a shopright only, "the matter will be considered to determine whether the activities of the Government are such that the shopright extends to the particular foreign country involved so as to require a similar stipulation in such foreign application."

Apparently, the latter determination will turn primarily on whether the United States is likely to use the invention in a given country; if this be the criterion the distinction will have little realistic significance.

However, the regulation is soundly intended to resolve in advance the innumerable complicated issues otherwise inevitably to be faced.

Because of the very serious question of validity of any regulations which do more than codify the existing legal rules-at least insofar as

44. United States v. Dubilier Condenser Corp., 289 U. S. $178,208-9,53$ Sup. Ct. 554, 565, 77 L. Ed. III4, II29-30 (1933), "Under what power, express or implied, may such officers, by administrative fiat, determine the nature and extent of rights exercised under a charter granted a patentee pursuant to constitutional and legislative provisions?"

45. Department of Interior, Order No. 1763 , Nov. $17,1942$.

46. Department of Agriculture, Circular No. 4, Aug. 12, 1943. 
present employees are concerned-there is little to be looked for at this time in any further departmental directives. In the absence of any court pronouncements as to the disposition of foreign patent rights, and obligations thereunder, we must apparently look to the Congress for clarification. The ultimate determination, to be sure, as to what construction will be given in regard to foreign patent rights must rest with the foreign courts to whom the problems are presented. A clearcut domestic policy as to the interpretation of those rights would, however, be of vital significance in the final settlement.

Inasmuch as a governmental employee is denied the right to recover for use of his United States patent by our Government except by a special act of Congress, his right to recover under a foreign patent will be of peculiar interest to him. If he should bring a claim for infringement against the British Government, based on its use of lendlease goods, the United States will presumably be required to indemnify the British to the extent of his recovery. Thus the employee will have done abroad what he could not do at home-recover from the United States for use of his invention. It is, of course, highly questionable whether the Congress could be persuaded thereafter to enact special legislation authorizing a further recovery against this Government because of its manufacture of the same lend-lease goods. But where his suit is against a country other than Great Britain and the United States is not obligated to indennify, Congress might be less reluctant to recognize his domestic claims.

A further problem involving the governmental employee arises in connection with Section 45 of 35 U. S. C. ${ }^{47}$ This section provides for an employee obtaining a patent without the payment of any fees

"Provided, that the applicant in his application shall state that the invention described therein, if patented, may be manufactured and used by or for the Government for governmental purposes without the payment to him of any royalty thereon, which stipulation shall be included in the patent."

Here again it is not clear whether the employee gives rights in his entire invention or simply in his United States patent. The statute uses both terms. It speaks first of "the invention described therein," but tends largely to counteract the effect of this by providing that the statement "shall be included in the patent." ${ }_{48}$ The conclusion is inev-

47. Act of Mar. 3, I883, as amended April 30, I928.

48. See also the Report of the Interdepartmental Patents Board, note 39 supra, at 2: "It has been held ... that this Act does not work a public dedication of a patent taken out under it . $\therefore$ but that it provides simply a free use of the patent to the Government .... otherwise leaving unrestricted ownership of the patent in the patentee." And Hazeltine v. Electric Service Engineering Corp., I8 F. (2d) 662, 668 (S. D. N. Y. I 926) : "It must be quite obvious from a reading of the statute that there can be no dedication thereunder until its provisions become operative by the grant of a patent." 
itable that the legislators simply did not foresee any problem of distinction between invention and patent, and so drew none. Assuming that the rights he conveys to the Government are in his invention, it would presumably follow that lend-lease use of the goods made thereunder would be "for governmental purposes," and hence would be no infringement.

Once again, however, a foreign court will presumably be called on to determine whether an employee, having availed himself of this section, is free to secure foreign patents under which he may exact compensation for infringement resulting from the use of articles made and sold by the United States Government. Obviously it will be preferable if the solution as to what foreign rights are retained by the inventor be made in this country. Particularly is this so since a determination now would enable this Government to obtain all necessary foreign rights from the proper person before continuing to accrue potential liability through its lend-lease shipments.

\section{Damages}

The question of the measure of damages recoverable in these bipatent situations is one of some complexity, as well as of novelty. When the Government, without license, makes a patented article in this country and immediately sends it to a foreign country and there sells (or lends or leases) it, the patentee is entitled to recover under his United States patent for infringement-i. e. the manufacture occurring in this country-and under his foreign patent for infringementi. e. the sale and use occurring abroad. The extent of his recovery in each case is, however, a question which it may be difficult to answer.

Only one case in this country has considered expressly the problem of the extent of recovery permissible for infringing manufacture in this country, where the use and sale were abroad. In Ketchum Harvester Co.v. Johnson Harvester $\mathrm{Co}_{0}{ }^{49}$ the court rejected the contention that damages should be merely nominal.

"Although the patent could give no protection abroad in the sale of machines abroad, it gave protection in the United States in making machines in the United States for sale abroad. The patent prevented all persons but the patentee from making in the United States. The privilege of making in the United States, for sale abroad, was valuable, as was shown by the fact that the

49. 8 Fed. 586-7 (C. C. N. D. N. Y. I88I). Accord: K. W. Ignition Co. v. Temco Electric Motor Co., 283 Fed. 873 (C. C. A. 6th, 1922). As holding that the patentee is entitled to monopolize the making of his device in the United States, as well as the using and selling, see Bullock Elec. \& Mfg. Co. v. Westinghouse Elec. \& Mfg. Co., I29 Fed. 105, I09 (C. C. A. 6th, 1904); Dorsey Harvester Co. v. Bradley Co., I2 Blatchf. 202, Fed. Cas. No. 4,015 (C. C. N. D. N. Y. 1874); Adriance, Platt \& Co. v. McCormick Co., 55 Fed. 288 (C. C. N. D. I11. 1893). 
defendant made in the United States for sale abroad. The plaintiff was entitled to that privilege exclusively, and to damages for its violation. It may be that in the case of manufacture in the United States, without sale anywhere, nominal damages only are to be allowed; but where such manufacture is followed by sale abroad, it cannot be said that the damages ought to be only nominal. It is true that the sale is the fruition, and gives the profit, and that the sale is abroad, and the patent does not cover the sale abroad. But the unlawful act of making is made hurtful by a sale, wherever made."

The plaintiff in bringing suit had asked for an award of five dollars for each infringing machine which had been made and sold in the United States by the defendant, and two and one-half dollars for each machine made in the United States and sold abroad. In discussing the amount of damages the court said:

"The legal damages for making and selling here may be, in some cases, greater than the legal damages for making here and selling abroad. . . The allowance to the plaintiff of only onehalf, on machines sold abroad, of the fee on machines sold here, is very liberal to the defendant. It is all the plaintiff asks, and is not to be regarded as establishing the rule that the same damages would not be proper for machines sold abroad and for machines sold here both being unlawfully made. The act of making, in either case, is necessary to enable the sale to be made; and, the making being unlawful, it is no injustice to attribute to the unlawful act all the consequences which flow from it."

It should be observed that in this case the plaintiff apparently had no foreign patents covering the devices, under which he might recover for the sale and use abroad. Whether the court would have been as anxious to allow full recovery for manufacture here if the tortious sale and use abroad could be the subject of further recovery is problematical.

Assuming that the dictum of this court were followed to the extent that a suit here resulted in full damages for lend-lease manufacture, the question would be squarely presented to the foreign court as to whether additional damages should be allowed for the use abroad, or whether nominal damages alone could be obtained.

If only partial damages were recoverable here, the foreign court might allow supplementary damages there for violation of the foreign patent. Such a rule would be based on the equity of the situation, allowing one full recovery for what is essentially one infringement. Following the technical niceties of the situation, however, the foreign court might allow a second full recovery abroad. ${ }^{50}$

50. The United States doctrine limiting a patentee to one recovery for infringement by a given article, regardless of the number of technical infringements involving that article, is not strictly parallel for there the numerous torts violate only a single 


\section{Conclusion}

It is evident from the foregoing that there remain to be solved a myriad of complexities apparently inherent in any military-economic undertaking of such magnitude as is ours. But that those problems must be left for haphazard solution by courts spread around the globe is neither essential nor advisable.

Insofar as there is any question as to liability abroad of goods made here, the attempt should be made at this time to secure full foreign patent rights. In the case of British rights this will be relatively simple under the authority of the Patent Interchange Agreement. Other rights must be sought by special negotiation.

The situation as to foreign patent rights of governmental employees should be clarified by the Congress to the end that the potential liability in this regard may either be eliminated or recognized, and as recognized be anticipated.

The whole matter of post-war patent claims should be anticipated at this time by the setting up of a commission especially equipped for the task. Its duties would include the immediate co-ordination of all phases of the problem, to the end that claims against our Government by foreign patent owners, and claims against foreign governments or manufacturers brought by United States nationals may be smoothly and expeditiously handled as they arise.

Only by such programs of preparedness will we be assured that the post-war jubilation will not be marred by the discord and lack of harmony which impeded the return to normalcy in the decade of the twenties.

property right, not two separate property rights. However, it is to an extent analogous for it holds that where a patentee has recovered his full damages for an infringing article he may receive no further damages. Were this carried over to the bi-patent situation it would allow only one full recovery of damages.

The English rule regarding recovery, which limits the plaintiff to damages, is summarized in Spencer, United States Patent Law System (I93r) 45-6. 